\title{
Authoritarianism and political preferences in 1980
}

\author{
DONN BYRNE and D. P. J. PRZYBYLA \\ State University of New York, Albany, New York 12222
}

\begin{abstract}
The relationship between authoritarianism and various sociopolitical attitudes and choices has been investigated repeatedly during past presidential campaigns. The supporters of the most conservative and most liberal of the candidates differ correspondingly in F scale scores. In 1980 the similarity among the three major candidates seemed great enough to blur this usual effect. Among 119 undergraduates, analysis of variance indicated that the supporters of Ronald Reagan were significantly $(p<.0001)$ higher in authoritarianism than were supporters of Jimmy Carter or John Anderson. Similarly, among 95 undergraduates, supporters of Alfonse D'Amato in the New York senatorial race were significantly $(p<.005)$ more authoritarian than supporters of Elizabeth Holtzman and Jacob Javits. Thus, as in previous years, the perceived liberal-conservative variations among candidates were differentially attractive to equalitarian-authoritarian variations among voters.
\end{abstract}

Since its publication in 1950 by Adorno, FrenkelBrunswik, Levinson, and Sanford, the California F Scale has been utilized in hundreds of investigations of the "authoritarian personality." Among the more consistent findings are those relating this personality variable to sociopolitical attitudes and choices.

The items themselves reflect a variety of psychological constructs, including submission (e.g., "Young people sometimes get rebellious ideas, but as they grow up they ought to get over them and settle down"), aggression (e.g., "Homosexuals are hardly better than criminals and ought to be severely punished"), projectivity (e.g., "Most people don't realize how much our lives are controlled by plots hatched in secret places"), and an exaggerated concern with the sexual behavior of others (e.g., "The wild sex life of the old Greeks and Romans was tame compared to some of the goings-on in this country, even in places where people might least expect it"). Nevertheless, those who respond in the authoritarian direction to such statements also tend to express generally conservative political beliefs (Adorno et al., 1950; Leventhal, Jacobs, \& Kudirka, 1964) and to adhere to conservative positions on such specific issues as socialized medicine (Mahler, 1953) and the war in Vietnam (Granberg \& Corrigan, 1972; Izzett, 1971).

There are also several investigations stretching over various presidential elections that indicate the tendency of authoritarian college students to prefer the most conservative of the available candidates and of equalitarians to support the most liberal candidate. For example, among a group of potential nominees in 1960 , the supporters of Orville Faubus had the highest mean scores on the F scale and those choosing Adlai Stevenson received the lowest scores (Wrightsman, Radloff, Horton, \& Mecherikoff, 1961). In the 1964 campaign, George Wallace backers were significantly more authoritarian than those of Lyndon Johnson, and those preferring Barry Goldwater were intermediate (Milton \& Waite, 1964). In 1968, Richard Nixon was the choice of the most authoritarian subjects, and Robert F. Kennedy drew those who were least authoritarian (Byrne \& Kelley, in press).

The 1980 election did not appear to offer choices that were quite as clear-cut with respect to political philosophy as those presented by many of these past campaigns. Of the three major contenders, Jimmy Carter, Ronald Reagan, and John Anderson are each self-described as "born-again Christians" desiring to be labeled as moderates. Each indicated a desire to balance the budget, strengthen the nation's defenses, and bring about a reduction in the regulatory role of the federal government. Given their similarity, it seemed very possible that, for the first time, the authoritarian proclivities of the electorate might be unrelated to political choice. The present study was undertaken to test that possibility.

\section{METHOD}

A total of 161 undergraduates enrolled in courses in the psychology department at The State University of New York at Albany participated anonymously as subjects on a voluntary basis. In October 1980, a few weeks prior to the election, each took a 22-item version of the F scale that is balanced for acquiescent response set (Cherry \& Byrne, 1977). In addition, they were asked to indicate their preferences in the presidential race and the New York senatorial race.

\section{RESULTS}

In the presidential contest, the candidates receiving only one vote (Clark, Commoner, Jackson, Brown, and Mickey Mouse) were eliminated from the analysis, as were the undecided. 
Table 1

Mean Authoritarianism (F Scale) Scores of the Supporters of the Three Major Presidential Candidates in 1980

\begin{tabular}{ccc}
\hline Candidate & $\begin{array}{c}\text { Mean F Scale } \\
\text { Score }\end{array}$ & $\begin{array}{c}\text { Percentage } \\
\text { of Sample }\end{array}$ \\
\hline Ronald Reagan & 95.4 & 29 \\
John Anderson & 71.6 & 59 \\
Jimmy Carter & 70.8 & 12 \\
\hline
\end{tabular}

Table 2

Mean Authoritarianism (F Scale) Scores of the Supporters of the New York Senatorial Candidates in 1980

\begin{tabular}{lcc}
\hline \multicolumn{1}{c}{ Candidate } & $\begin{array}{c}\text { Mean F Scale } \\
\text { Score }\end{array}$ & $\begin{array}{c}\text { Percentage } \\
\text { of Sample }\end{array}$ \\
\hline Alfonse D'Amato & 94.8 & 23 \\
Jacob Javits & 75.5 & 36 \\
Elizabeth Holtzman & 74.0 & 41 \\
\hline
\end{tabular}

The mean scores of the remaining 119 subjects on the F scale are shown in Table 1, along with the percentage of students expressing each preference. It may be seen that, just as in studies conducted during previous campaigns, the dispositional variable of authoritarianism is significantly related to presidential choice. As indicated by analysis of variance, the supporters of the three major candidates differ in their scores on the California $F$ Scale $[F(2,116)=27.36, p<.0001]$. NewmanKeuls comparisons indicated that the Reagan supporters were significantly higher in authoritarianism than were those of the other two candidates and that the Anderson and Carter adherents did not differ from each other in this respect.

A similar analysis for the New York senatorial candidates (see Table 2) also revealed political choice to be associated with authoritarianism. Among the 95 students expressing a preference among the three candidates in this race, analysis of variance revealed a significant difference in test scores $[F(2,92)=5.56, p<.005]$. Further, Newman-Keuls comparisons indicated that the supporters of Alfonse D'Amato received the highest scores on the F scale, whereas those supporting Elizabeth Holtzman and Jacob Javits did not differ from each other.

\section{DISCUSSION}

It should be noted that the present results are quite consistent with those conducted in previous years. Potential voters in 1980 apparently were able to discern differences among candidates in either philosophy or style that are differentially appealing to individuals falling at various points along the dimension of authoritarianism. Such results were obtained even though a student sample is obviously selective compared with the total population of voters with respect to age, intelligence, educational attainment, and liberalism. Despite the fact that a restricted range on these variables acts against the likelihood of finding a relationship between a personality variable and voting choice, a relationship was found.

It might also be pointed out that in the presidential race, this group expressed a choice quite divergent from that of New York residents as reflected in statewide returns (Anderson was their first choice, rather than Reagan). In the senate race, the present responses also differed from those of the general population (Holtzman was first choice among students and D'Amato was the first choice of the electorate).

It is good to remember that authoritarianism is only one of several determinants of political preference. Research has shown that voting decisions are made on rational grounds, such as agreement with the candidate's views (Byrne, Bond, \& Diamond, 1969), and on relatively less rational grounds, such as the candidate's physical attractiveness (Efran \& Patterson, 1974) and the number of repeated exposures he or she has been able to purchase (Grush, McKeough, \& Ahlering, 1978). In that respect, the role of authoritarianism could be characterized as a reasonable attempt to put into office those who are perceived as most likely to satisfy one's ideological needs.

\section{REFERENCES}

Adorno, T. W., Frenkel-Brunswik, E., Levinson, D. J., \& SANFORD, R. N. The authoritarian personality. New York: Harper, 1950.

Byrne, D., Bond, M. H., \& Diamond, M. J. Response to political candidates as a function of attitude similarity-dissimilarity. Human Relations, 1969, 22, 251-267.

Byrne, D., \& Kelley, K. An introduction to personality. Englewood Cliffs, N.J: Prentice-Hall, in press.

Cherry, F., \& Byrne, D. Authoritarianism. In T. Blass (Ed.), Personality variables in social behavior. Hillsdale, N.J: Erlbaum, 1977.

Efran, M. G., \& Patterson, E. W. J. Voters vote beautiful: The effect of physical appearance on a national election. Canadian Journal of Behavioral Science, 1974, 6, 352-356.

Granberg, D., \& Corrigan, G. Authoritarianism, dogmatism, and orientations toward the Vietnam war. Sociometry, 1972, $35,468-476$.

Grush, J. E., McKeough, K. L., \& Ahlering, R. F. Extrapolating laboratory exposure research to actual political elections. Journal of Personality and Social Psychology, 1978, 36, 257-270.

IzzeTT, R. R. Authoritarianism and attitudes toward the Vietnam war as reflected in behavioral and self-report measures. Journal of Personality and Social Psychology, 1971, 17, 145-148.

Leventhal, H. JacoBs, R. L., \& Kudirka, N. Z. Authoritarianism, ideology, and political candidate choice. Journal of Abnormal and Social Psychology, 1964, 69, 539-549.

Mahler, I. Attitudes toward socialized medicine. Journal of Social Psychology, 1953, 38, 273-282.

Milton, W., \& W Aite, B. Presidential preference and traditional family values. American Psychologist, 1964, 19, 844-845.

Wrightsman, L. S., Jr., Radloff, R. W., Horton, D. L., \& MecherikofF, M. Authoritarian attitudes and presidential voting preferences. Psychological Reports, 1961, 8, 43-46.

(Received for publication November 20, 1980.) 